\title{
Carotenoids and Ubiquinone in Aerobically Grown Cells of an Aerobic Photosynthetic Bacterium, Erythrobacter Species OCh 114
}

\author{
Keiji Harashima and Hirohisa NaKada \\ Department of Agricultural Chemistry, Faculty of Agriculture, \\ The University of Tokyo, Bunkyo-ku, Tokyo 113, Japan
}

Received November 12, 1982

\begin{abstract}
Carotenoids and ubiquinone in aerobically grown cells of Erythrobacter species OCh 114 were identified, which contained a considerable amount of bacteriochlorophyll $a$ mediating light-driven electron flows. Spheroidenone was found to be the major component of carotenoids. Also small amounts of 2,2'-diketospirilloxanthin and $\mathrm{OH}$-spheroidenone were found. Since symmetrical $\zeta$ carotene (together with phytoene and phytofluene) was accumulated in diphenylamine-inhibited cultures, these 3 keto carotenoids of the alternative spirilloxanthin-series are considered to be synthesized mainly via symmetrical $\zeta$-carotene and not through asymmetrical $\zeta$-carotene which is known to be the intermediate in the biosynthesis of carotenoids in some species of non-sulfur purple bacteria. On the other hand, the major (or the sole) respiratory quinone of this strain was found to be ubiquinone-10.
\end{abstract}

Shiba et al. ${ }^{1)}$ isolated many strains of marine organotrophic bacteria containing $\mathrm{Bchl} a .^{2 \sim 3)}$ Since they did not grow anaerobically even in the light and could not be classified into known genera of photosynthetic bacteria, a novel genus, Erythrobacter, was proposed for these bacterial strains. ${ }^{4)}$ In contrast to typical photosynthetic bacteria, these bacterial strains synthesized Bchl well aerobically, but only to a limited extent under semi-aerobic conditions. ${ }^{5}$ ) Moreover, Bchl synthesized in aerobically grown cells of these bacteria mediated lightdriven electron flows. ${ }^{6)}$ Therefore, they may be called aerobic photosynthetic bacteria and their taxonomical relation to non-sulfur purple bacteria is of interest.

In connection with this, analysis of carotenoids, which are responsible for colors (red and orange) of cells of these bacteria, seems to be important. This communication reports the identification of carotenoids in OCh 114 , as a representative of the red-colored strains of Erythrobacter. ${ }^{3)}$ Also identification of the major respiratory quinone was undertaken.

\section{MATERIALS AND METHODS}

Bacterial strains. Erythrobacter species strain OCh 114 was a gift from Dr. Shiba, Otsuchi Marine Research Center (The University of Tokyo), and had been maintained on PPES-II agar medium. ${ }^{7)}$ Also strains of Rhodopseudomonas capsulata and Rp. gelatinosa were obtained from him too.

Chromatography. Aluminum oxide (Merck) was used for column chromatography after being washed with water and dried as described previously. ${ }^{87}$ Kieselgel G (Merck, Type 60) was used for TLC of carotenoids and cellulose precoated TLC plates (Merck, without fluorescent indicator, $0.1 \mathrm{~mm}$ thickness) were used for TLC of UQs.

Stepwise borohydride-reduction and measurement of partition coefficients. Stepwise borohydride-reduction and measurement of partition coefficients (between hexane and aqueous methanol) of keto carotenoids were carried out as described previously. ${ }^{8)}$

Authentic samples of carotenoids and UQs. Spheroidenone was prepared from a culture of $R p$. capsulata (NCIB 8254$)^{9,10)}$ grown anaerobically in the light and then vigorously aerated for $18 \mathrm{hr} .{ }^{11)}$ The lipid fraction obtained by acetone-extraction was fractionated by chromatography on a column of aluminum oxide. All-trans- 
spheroidenone, eluted from the column with benzenehexane $(1: 3)$, was purified by crystallization from benzene-hexane. From the fraction eluted between spheroidene and all-trans-spheroidenone, UQ-10 ${ }^{12)}$ was isolated by crystallization from hot ethanol. Recrystallization of the crude preparation from acetone yielded a carotenoid-free preparation used as the authentic sample.

Neurosporene, spheroidene, 2,2'-diketospirilloxanthin and $\mathrm{OH}$-spheroidenone were prepared from $R p$. gelatinosa $(\text { NCIB } 8290)^{9,10,13,14)}$ cultured on a glutamate-yeast extract medium $^{13}$ ) anaerobically in the light and then vigorously aerated for $18 \mathrm{hr} .{ }^{11)}$ Also UQ-8 was prepared from cultures of $R p$. gelatinos ${ }^{12)}$ as described above for UQ-10 from $R p$. capsulata.

Symmetrical $\zeta$-carotene was prepared from carrot roots as described by Davies. ${ }^{15)}$

Culture and extraction of carotenoids and $U Q$. Erythrobacter species OCh 114 was cultured aerobically in 1 liter-batches as described previously ${ }^{5)}$ on an enriched PPES-II medium at $25^{\circ} \mathrm{C}$ in the dark for 3 days. The bacterial cells were harvested by centrifugation and washed once with an aqueous $3 \%$ solution of sodium chloride and stored frozen at $-20^{\circ} \mathrm{C}$ until use. A total $110 \mathrm{~g}$ of packed cell mass obtained from a total 20 liters of cultures was submitted to extraction with acetone.
In the case of diphenylamine-inhibited cultures, diphenylamine $(65 \mu \mathrm{M})$ was added to the medium $20 \sim 22 \mathrm{hr}$ after inoculation of the bacteria as described by Davies. ${ }^{15)}$ A total $14 \mathrm{~g}$ of packed cell mass (obtained from a total 4 liters of diphenylamine-inhibited cultures) was submitted to extraction with acetone.

Frozen cells $(30 \sim 40 \mathrm{~g})$ were soaked in $300 \sim 400 \mathrm{ml}$ of acetone at $4^{\circ} \mathrm{C}$ in the dark overnight and then filtered off. Extraction was repeated more 3 times and the acetone extracts were combined. The combined extract was diluted with 1 liter of distilled water and extracted 3 times each with $500 \mathrm{ml}$ of a mixture of benzene and hexane $(1: 1)$. The combined extract was washed 4 times with an aqueous saturated solution of sodium chloride, dried over anhydrous sodium sulfate and evaporated in vacuo. The darkcolored residue was dissolved in a minimum volume of a mixture of benzene and hexane $(1: 4)$, filtered through a glass-filter and submitted to fractionation by column chromatography.

In the case of diphenylamine-inhibited cultures, bacterial cells were extracted with acetone as described above and the combined acetone-solution was extracted with hexane (instead of benzene-hexane $1: 1$ ) after being diluted with water. The extract in hexane was evaporated in vacuo and the residue was dissolved in a small volume of hexane. The resulting solution was filtered and submitted to chromatography on aluminum oxide.

Table I. Fractionation of Carotenoids AND UQ in Erythrobacter Species OCh 114 by Chromatography on Aluminum Oxide

\begin{tabular}{|c|c|c|c|c|c|}
\hline Fractions & $\begin{array}{l}\text { Colors } \\
\text { of } \\
\text { bands }\end{array}$ & $\begin{array}{l}\text { Solvents } \\
\text { for } \\
\text { elution }\end{array}$ & $\begin{array}{c}\text { Fractions } \\
\text { obtained } \\
\text { by TLC }\end{array}$ & Identification & $\begin{array}{c}\text { Relative amounts } \\
\text { of } \\
\text { carotenoids }\end{array}$ \\
\hline I & Pale yellow & $\begin{array}{l}\text { Benzene-hexane } \\
(1: 4)\end{array}$ & $\left\{\begin{array}{l}\mathrm{I}-\mathrm{a} \\
\mathrm{I}-\mathrm{b}\end{array}\right.$ & $\begin{array}{l}\text { Symmetrical } \\
\zeta \text {-carotene } \\
\text { Neurosporene }\end{array}$ & $<0.1 \%$ \\
\hline II & Red & $\begin{array}{l}\text { Benzene-hexane } \\
(1: 3)\end{array}$ & - & $\left\{\begin{array}{l}\text { UQ-10 } \\
\text { cis-Spheroidenone }\end{array}\right.$ & $\frac{-(29 \mathrm{mg})^{b}}{10.0}$ \\
\hline III & Reddish purple & $\begin{array}{l}\text { Benzene-hexane } \\
(1: 2)\end{array}$ & - & Spheroidenone & $86.9(27 \mathrm{mg})^{b}$ \\
\hline IV & Purple & Benzene & $\left\{\begin{array}{l}\text { IV-a } \\
\text { IV-b } \\
\text { IV-c } \\
\text { IV-d }\end{array}\right.$ & $\begin{array}{l}\text { 2,2'-Diketo- } \\
\text { spirilloxanthin } \\
\text { n.i. } .^{c} \\
\text { n.i. }{ }^{d} \\
\text { n.i. }{ }^{e}\end{array}$ & 0.6 \\
\hline $\mathbf{V}$ & Reddish purple & $\begin{array}{l}\text { Benzene-acetone } \\
(50: 1)\end{array}$ & - & OH-Spheroidenone & 1.7 \\
\hline
\end{tabular}

a Careful elution enabled us to separate UQ from cis-spheroidenone. In such a case, UQ eluted from the column faster than cis-spheroidenone.

$b$ The yields of purified preparation from $110 \mathrm{~g}$ of the bacterial cells.

c Not identified. $\lambda_{\max }$ (in hexane), 449 and $478 \mathrm{~nm}$.

${ }^{d}$ Not identified. $\lambda_{\max }$ (in hexane), 464 and $498 \mathrm{~nm}$.

$e$ A mixture of miscellaneous unidentified components showing no definite absorption maximum. 
Fractionation of carotenoids and UQ. The concentrated lipid extract obtained from $30 \sim 40 \mathrm{~g}$ of cells (as described above) was loaded on a column $(13 \times 80 \mathrm{~mm})$ of $10 \mathrm{~g}$ of aluminum oxide deactivated with $0.2 \mathrm{ml}$ of distilled water. Carotenoids and UQ adsorbed on the top of the column were eluted successively with benzene-hexane $(1: 4,50 \mathrm{ml})$, benzene-hexane $(1: 3, \quad 150 \sim 200 \mathrm{ml})$, benzene-hexane $(1: 2,300 \mathrm{ml})$, benzene $(300 \mathrm{ml})$ and finally benzeneacetone $(50: 1,200 \mathrm{ml})$. The eluates collected separately (Table I) were evaporated and submitted to further fractionation and purification.

Spectroscopy. Ultraviolet and visible absorption spectra were recorded with a Hitachi Model 124 spectrophotometer equipped with a recorder (Model 056). Mass spectrometric cracking patterns of carotenoids were recorded by direct insertion with a Hitachi Model RMU-6M singlefocusing mass spectrometer and those of UQs were recorded by direct insertion with a Shimadzu single-focusing mass spectrometer (Model $9000 \mathrm{~S}$ ). Mass numbers of molecular ion-peaks were calibrated with authentic samples of carotenoids and UQs.

\section{RESULTS}

\section{$\zeta$-Carotene and neurosporene}

Fraction I was a mixture of 2 components which were separated by TLC on silica-gel G. One of them (Fr. I-a), that ran faster on a thin layer plate, did not separate from authentic symmetrical $\zeta$-carotene $\left(7,8,7^{\prime}, 8^{\prime}\right.$-tetrahydro$\psi, \psi$-carotene) (Table III). However, the amount of this component obtained was too small to allow further characterization. Therefore, this component was isolated from diphenylamine-inhibited cultures of Erythrobacter species OCh 114. Fr. I (obtained from the diphenylamine-inhibited cultures) was fractionated by rechromatography on aluminum oxide. Elution of components in this fraction was done with hexane containing increasing concentrations of diethylether. ${ }^{16)}$ Elution of phytoene and phytofluene, followed by elution of Fr. I-a and Fr. I-b was observed. Fr. I-a, purified by further rechromatography, gave an ultraviolet-visible absorption spectrum similar to that of symmetrical $\zeta$-carotene (Fig. 1). Since the absorbance at $399.5 \mathrm{~nm}$ was slightly higher than that at $425.5 \mathrm{~nm}$, possible contamination of this fraction by asymmetrical $\zeta$-carotene $(7,8,11,12$-tetrahydro- $\psi, \psi$ carotene) can not be completely ruled out. ${ }^{16)}$

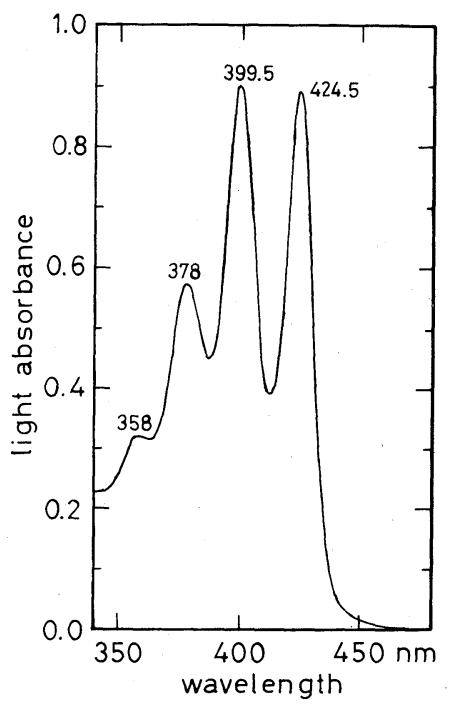

FIG. 1. Ultraviolet-visible Absorption Spectrum (in Hexane) of the Carotenoid in Fr. I-a Obtained from Diphenylamine-inhibited Cultures of Erythrobacter Species OCh 114.

Nevertheless, the major component of Fr. I-a is considered to be symmetrical $\zeta$-carotene. We could not obtain any fraction showing an absorption spectrum similar to that of asymmetrical $\zeta$-carotene.

Another component of Fr. I (Fr. I-b) showed a visible absorption spectrum $\left(\lambda_{\max }\right.$ : $415,438,468 \mathrm{~nm}$ in hexane) similar to that of neurosporene (7,8-dihydro- $\psi, \psi$-carotene) ${ }^{14)}$ When a mixture of this specimen and authentic neurosporene was submitted to TLC, only one spot was observed (Table III). Therefore, this component was identified as neurosporene.

\section{cis-Spheroidenone and UQ-10}

The visible absorption spectrum of Fraction II ( $\lambda_{\text {max }}: 477,508 \mathrm{~nm}$ in hexane) was similar to that of a cis-isomer of spheroidenone. ${ }^{17)}$ Moreover, rechromatography of this fraction always yielded the Fr. III-carotenoid. Therefore, the carotenoid in Fr. II was assumed to be a cis-isomer of the Fr. IIIcarotenoid (spheroidenone), and further characterization was not undertaken.

On the other hand, this fraction showed an ultraviolet absorption spectrum $\left(\lambda_{\max }: 272 \mathrm{~nm}\right.$ in hexane) similar to that of UQs and, after 
being evaporated in vacuo, gave orange-yellow crystals upon successive recrystallization from hot ethanol and acetone. The yields of the purified material (almost carotenoid-free, $\mathrm{mp}$ $48.5 \sim 49.5^{\circ} \mathrm{C}^{*}$ ) was $29 \mathrm{mg}$ from a total $110 \mathrm{~g}$ of the bacterial cells. The ultraviolet absorption spectra of this purified specimen, before and after reduction with borohydride (Fig. 2), were completely identical to those of UQs. ${ }^{19)}$ TLC of this specimen on a cellulose-plate, impregnated with white vaseline, gave a single spot which separated from UQ-8 but not from UQ10 (Fig. 2). Mass analysis of this specimen showed a molecular ion-peak at $\mathrm{m} / \mathrm{z}: 862$ $\left(\mathrm{C}_{59} \mathrm{H}_{90} \mathrm{O}_{4}\right.$ for UQ-10) and fragmental ionpeaks at $m / z$ : 197 and 235, which were characteristic of mass spectra of UQs. ${ }^{22)}$ Therefore, this compound was identified as UQ-10.

\section{Spheroidenone}

When Fr. III was evaporated in vacuo and the residue was treated with hexane, beautiful red crystals precipitated, and it was not separated by TLC from authentic spheroidenone (1-methoxy-3,4-didehydro-1,2,7',8' -tetrahydro- $\psi, \psi$-caroten-2-one) (Table III). Re-

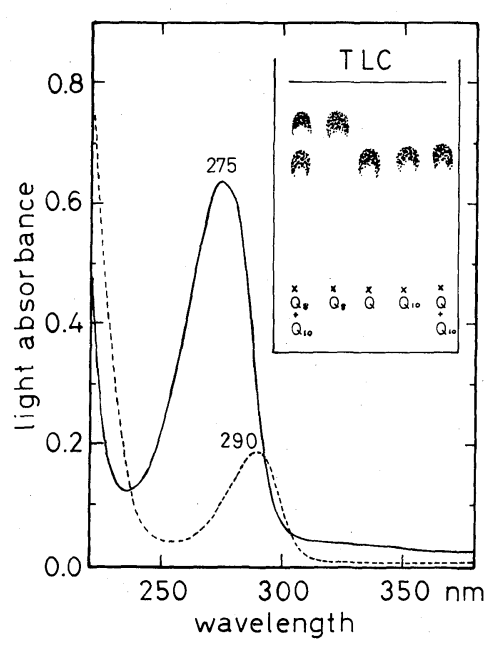

FIG. 2. Ultraviolet Absorption Spectra (in Ethanol), before (-) and after (-----) Reduction with $\mathrm{NaBH}_{4}$, and TLC of UQ of Erythrobacter Species OCh 114.

UQs were dissolved in acetone and subjected to TLC on cellulose impregnated with white vaseline according to the method of reversed phase paper partition chromatography described by Gale et al. ${ }^{20)}$ and Yamada et al. ${ }^{21}$ The solvent for development was a 97:3 mixture of $N, N$ dimethylformamide and distilled water. Spots of UQs were visualized by dipping the TLC-plate, after development, into an aqueous $0.2 \%$ solution of $\mathrm{KMnO}_{4}$. Q, UQ from OCh 114; $\mathrm{Q}_{8}$, UQ-8; $\mathrm{Q}_{10}$, UQ-10.

Table II. Visible Absorption Spectra of Keto Carotenoids in Erythrobacter OCh SPECIES OCh 114

\begin{tabular}{|c|c|c|c|c|c|c|}
\hline \multirow{2}{*}{ Carotenoids } & \multicolumn{6}{|c|}{$\lambda_{\max }(\mathrm{nm})$} \\
\hline & \multicolumn{3}{|c|}{ In hexane } & \multicolumn{3}{|c|}{ In benzene } \\
\hline Fr. III & - & 482 & 513 & - & 499 & $532^{a}$ \\
\hline Spheroidenone & - & 482 & 513 & - & 499 & $532^{a}$ \\
\hline Reduced Fr. III & 428 & 453 & 485 & 440 & 466.5 & 499.5 \\
\hline Spheroidene $^{b}$ & 427 & 453 & 483 & & - & \\
\hline Fr. IV-a & $(486$ & 517 & $553)^{b}$ & - & 540 & 578 \\
\hline $\begin{array}{l}\text { 2,2'-Diketo- } \\
\text { spirilloxanthin }\end{array}$ & 487 & 518 & 555 & - & 540 & 578 \\
\hline Reduced Fr. IV-a & 462 & 490 & 523 & 478 & 508 & 543 \\
\hline Spirilloxanthin ${ }^{c}$ & 465 & 493 & 527 & $480-1$ & 510 & 546 \\
\hline Fr. V & - & 482 & 513 & - & 499 & $531^{a}$ \\
\hline OH-Spheroidenone & - & 482 & 513 & - & 499 & $531^{a}$ \\
\hline Reduced Fr. V. & 429 & 453 & 485 & & - & \\
\hline
\end{tabular}

a Shoulder.

b Crude preparation.

c Cited from the literature. ${ }^{23)}$ 
TABle III. $R f$-VALUES OF CAROTENOIDS IN Erythrobacter SPECIES OCh 114 ON Silica-gel G Plates

\begin{tabular}{|c|c|c|}
\hline Carotenoids & $R f$ & Solvents for development \\
\hline $\begin{array}{l}\text { Fr. I-a } \\
\text { Symmetrical } \\
\zeta \text {-carotene }\end{array}$ & $\begin{array}{l}0.36 \\
0.36\end{array}$ & 0 \\
\hline $\begin{array}{l}\text { Fr. I-b } \\
\text { Neurosporene }\end{array}$ & $\begin{array}{l}0.31 \\
0.31\end{array}$ & \\
\hline $\begin{array}{l}\text { Fr. III } \\
\text { Spheroidenone }\end{array}$ & $\begin{array}{l}0.56 \\
0.57\end{array}$ & Benzene-acetone $(20: 3)$ \\
\hline $\begin{array}{l}\text { Fr. IV-a } \\
\text { 2,2'-Diketo- } \\
\quad \text { spirilloxanthin }\end{array}$ & $\begin{array}{l}0.51 \\
0.51\end{array}$ & Benzene-hexane-acetone \\
\hline $\begin{array}{l}\text { Fr. V } \\
\text { OH-Spheroidenone }\end{array}$ & $\begin{array}{l}0.27 \\
0.27\end{array}$ & \\
\hline
\end{tabular}

crystallization of this preparation from benzene-hexane $(1: 6)$ gave crystals showing visible absorption spectra (Table II) identical to those of spheroidenone. The yield was $27 \mathrm{mg}$ from a total $110 \mathrm{~g}$ of the bacterial cells (mp $157.5 \sim 159^{\circ} \mathrm{C}^{*}$ in an evacuated tube). One step-reduction of this substance with borohydride gave a product showing a visible absorption spectrum similar to that of spheroidene (1-methoxy-3,4-didehydro-1,2,7', $8^{\prime}$ tetrahydro- $\psi, \psi$-carotene) (Table II). The partition coefficient of this compound coincided with that of authentic spheroidenone (Table IV), and mass analysis showed a molecular ion-peak at $m / z$ : $582\left(\mathrm{C}_{41} \mathrm{H}_{58} \mathrm{O}_{2}\right.$ for spheroidenone). Therefore, the carotenoid in Fr. III was identified as spheroidenone.

\section{2,2'-Diketospirilloxanthin}

Four components were found in Fraction IV, of which only one (Fr. IV-a) was identified. The amounts of the other three components (Fr. IV-b, IV-c and IV-d) were too small to permit further characterization.

Fr. IV-a was purified by repeated TLC on silica-gel $\mathrm{G}$. The purified material precipitated from hexane and was sparingly soluble in
Table IV. Partition Coefficients of Keto CAROTENOIDS IN Erythrobacter SPECIES OCh 114 Between HeXane and Aqueous Methanol

\begin{tabular}{|c|c|c|}
\hline \multirow{2}{*}{ Carotenoids } & \multicolumn{2}{|c|}{$\begin{array}{c}\text { Concentration }(\mathrm{v} / \mathrm{v}) \\
\text { of methanol }\end{array}$} \\
\hline & $99 \%$ & $97.5 \%$ \\
\hline $\begin{array}{l}\text { Fr. III } \\
\text { Spheroidenone }\end{array}$ & $\begin{array}{cc}a & b \\
76.9: 23.1 \\
76.5: 23.5\end{array}$ & ${ }^{a}{ }_{-}^{b}$ \\
\hline $\begin{array}{l}\text { Fr. IV-a } \\
2,2^{\prime} \text {-Diketo- } \\
\quad \text { spirilloxanthin }\end{array}$ & $\begin{array}{l}44.0: 56.0 \\
43.3: 56.7\end{array}$ & $\begin{array}{l}52.6: 47.4 \\
52.1: 47.9\end{array}$ \\
\hline $\begin{array}{l}\text { Fr. V } \\
\text { OH-Spheroidenone }\end{array}$ & $\begin{array}{l}29.3: 70.7 \\
31.8: 68.2\end{array}$ & $\begin{array}{l}33.5: 66.5 \\
35.6: 64.4\end{array}$ \\
\hline
\end{tabular}

a, epiphase; b, hypophase.

hexane. The visible absorption spectra of this specimen (Table II) were essentially identical to those of authentic 2,2'-diketospirilloxanthin (1, $1^{\prime}$-dimethoxy-3,4,3', $4^{\prime}$-tetradehydro-1,2, $1^{\prime}$,$2^{\prime}$-tetrahydro- $\psi, \psi$-carotene-2,2'-dione). Two step-reduction of this compound with borohydride afforded a product showing visible absorption spectra similar to those of spirilloxanthin (1, $1^{\prime}$-dimethoxy-3,4,3', $4^{\prime}$-tetradehydro-1,2,1',2'-tetrahydro- $\psi, \psi$-carotene) (Table II). TLC of this specimen gave a spot which did not separate from authentic 2,2'diketospirilloxanthin (Table III). The partition coefficients of this specimen coincided with those of authentic 2,2'-diketospirilloxanthin (Table IV), and mass analysis showed a molecular ion-peak at $m / z: 624\left(\mathrm{C}_{42} \mathrm{H}_{56} \mathrm{O}_{4}\right.$ for 2,2'-diketospirilloxanthin). Therefore, the carotenoid in Fr. IV-a was identified as 2,2'diketospirilloxanthin.

\section{OH-Spheroidenone}

The carotenoid in Fraction $\mathrm{V}$ was purified further by TLC on silica-gel G. The purified material, recrystallized from benzene-hexane $(1: 6)$, showed visible absorption spectra similar to those of spheroidenone or $\mathrm{OH}$ -

* Melting points of UQ-10 and spheroidenone were reported to be $49.5 \sim 50.5^{\circ} \mathrm{C}^{18)}$ and $\left.158 \sim 159^{\circ} \mathrm{C},{ }^{17}\right)$ respectively. 
spheroidenone (1'-hydroxy-1-methoxy-3,4didehydro-1,2, $1^{\prime}, 2^{\prime}, 7^{\prime}, 8^{\prime}$-hexahydro- $\psi, \psi$ caroten-2-one) (Table II), and did not separate from authentic $\mathrm{OH}$-spheroidenone upon TLC (Table III). One step-reduction of this material with borohydride afforded a product showing a visible absorption spectrum similar to that of spheroidene (Table II). The partition coefficients of this specimen coincided with those of $\mathrm{OH}$-spheroidenone (Table IV), and mass analysis showed a molecular ion-peak at $m / z$ : $600\left(\mathrm{C}_{41} \mathrm{H}_{60} \mathrm{O}_{3}\right.$ for $\mathrm{OH}$-spheroidenone). Therefore, the carotenoid in Fr. V was identified as $\mathrm{OH}$-spheroidenone.

\section{DISCUSSION}

Table I also shows the relative amounts of carotenoids in aerobically grown cells of Erythrobacter species OCh 114. Spheroidenone (all-trans and a cis) comprised more than 95\% of the total carotenoids. Several minor carotenoids were found, of which 2,2'-diketospirilloxanthin and $\mathrm{OH}$-spheroidenone comprised about $2.5 \%$ of the total carotenoids. This composition resembles that reported for aerobic cultures of Rhodopseudomonas spheroides. ${ }^{9}$ However, the total amount of carotenoids in aerobically grown cells of OCh 114 was considerably higher than that found in semiaerobically grown cells. ${ }^{5)}$ This is a distinct difference between Erythrobacter species OCh 114 and $R p$. spheroides. Moreover, in the case of OCh 114, neither spheroidene, spirilloxanthin nor $\mathrm{OH}$-spheroidene was detected. Besides the three keto carotenoids of the alternative spirilloxanthin-series, trace amounts of symmetrical $\zeta$-carotene and neurosporene were found. In the presence of diphenylamine, which inhibits synthesis of fully unsaturated polyenes, accumulation of phytoene, phytofluene and symmetrical $\zeta$-carotene was observed. It is well known, that some typical non-sulfur purple bacteria (for example, Rhodospirillum rubrum $^{15)}$ and Rhodopseudomonas globiformis $^{24)}$ ) synthesize carotenoids via asymmetrical $\zeta$-carotene. However, carotenoids in $\mathrm{OCh}$
114 are assumed to be synthesized mainly via symmetrical $\zeta$-carotene, although a possibility is not completely ruled out, that a minor part of the carotenoids is synthesized via asymmetrical $\zeta$-carotene.

On the other hand, UQ-10 was found as the sole (or the major) respiratory quinone. Since no quinone was detected in fractions other than Fr. II, menaquinone seems to be absent from this strain. The amount of UQ-10 found in cells of this strain is considerably high (30 35 mg of UQ-10 were found in Fr. II, before purification, obtained from a total $110 \mathrm{~g}$ of cells).

The composition of carotenoids and quinone in Erythrobacter species OCh 114 described above suggests a taxonomical relationship of Erythrobacter to Rhodospirillaceae. However, conclusive evidence for the taxonomical distance between Erythrobacter and genera of the Rhodospirillaceae awaits further biochemical and genetic studies.

Acknowledgments. We are indebted to Mrs. Y. Koiso, the Institute of Applied Microbiology (The University of Tokyo), for mass analysis of UQs, and to Dr. T. Shiba, Otsuchi Marine Research Center (The University of Tokyo), for the gift of the bacterial strains.

\section{REFERENCES}

1) T. Shiba, U. Simidu and N. Taga, Appl. Environ. Microbiol., 38, 43 (1979).

2) K. Harashima, T. Shiba, T. Totsuka, U. Simidu and N. Taga, Agric. Biol. Chem., 42, 1627 (1978).

3) T. Shiba, U. Simidu and N. Taga, Bull. Jpn. Soc. Sci. Fish., 45, 801 (1979).

4) T. Shiba and U. Simidu, Int. J. Syst. Bacteriol., 32, 211 (1982).

5) $\dot{K}$. Harashima, J. Hayasaki, T. Ikari and T. Shiba, Plant Cell Physiol., 21, 1283 (1980).

6) K. Harashima, M. Nakagawa and N. Murata, Plant Cell Physiol., 23, 185 (1982).

7) N. Taga, Bull. Misaki Mar. Biol. Inst. Kyoto Univ., 12, 56 (1968).

8) K. Harashima, Int. J. Biochem., 1, 523 (1970).

9) T. W. Goodwin, Arch. Mikrobiol., 24, 313 (1956).

10) M. S. Barber, L. M. Jackman, P. S. Manchand and B. C. L. Weedon, J. Chem. Soc. C, 2166 (1966).

11) K. E. Eimhjellen and S. Liaaen Jensen, Biochim. Biophys. Acta, 82, 21 (1964).

12) J. Maroc, H. De Klerk and M. D. Kamen, Biochim. Biophys. Acta, 162, 621 (1968). 
13) L. M. Jackman and S. Liaaen Jensen, Acta Chem. Scand., 18, 1403 (1964).

14) S. Liaaen Jensen, Acta Chem. Scand., 17, 489 (1963).

15) B. H. Davies, Biochem. J., 116, 93 (1970).

16) B. H. Davies, C. J. Hallett, R. A. London and A. F. Rees, Phytochemistry, 13, 1209 (1974).

17) S. Liaaen Jensen, Acta Chem. Scand., 17, 303 (1963).

18) D. E. Wolf, C. H. Hoffman, N. R. Trenner, B. H. Arison, C. H. Shunk, B. O. Linn, J. F. McPherson and K. Folkers, J. Am. Chem. Soc., 80, 4752 (1958).

19) F. L. Crane and R. Barr, Determination of Ubiquinones, in "Methods in Enzymology," Vol. $18 \mathrm{C}$, ed. by D. B. McCormick and L. D. Wright,
Academic Press, New York and London, 1971, pp. $137 \sim 165$.

20) P. H. Gale, B. H. Arison, N. R. Trenner, A. C. Page, Jr. and K. Folkers, Biochemistry, 2, 196 (1963).

21) Y. Yamada, Y. Kanematsu, M. Ôhashi and K. Kondô, Agric. Biol. Chem., 37, 621 (1973).

22) Y. Yamada, K. Aida and T. Uemura, Agric. Biol. Chem., 32, 786 (1968).

23) A. Polgár, C. B. van Niel and L. Zechmeister, Arch. Biochem., 5, 243 (1944).

24) K. Schmidt and S. Liaaen-Jensen, Acta Chem. Scand., 27, 3040 (1973). 